\title{
Cultured human cells with high levels of gold-binding cytosolic metallothionein are not resistant to the growth inhibitory effect of sodium aurothiomalate
}

\author{
A GLENNÅS ${ }^{12}$ AND H E RUGSTAD \\ From the ${ }^{1}$ Division of Clinical Pharmacology, Institute for Surgical Research, Rikshospitalet, the National \\ Hospital, and ${ }^{2}$ Oslo Sanitetsforening Rheumatism Hospital, Oslo, Norway
}

SUMMARY We have previously shown that cells with a high content of the gold-binding protein metallothionein (MT) are resistant to the growth inhibitory effects of gold(III) chloride and auranofin. To investigate whether MT confers resistance to sodium aurothiomalate two cell lines of cultured human epithelial (HE) cells were used; the parental cell line (HE) and a substrain $\left(\mathrm{HE}_{100}\right)$ containing high levels of cytosolic MT. Sodium aurothiomalate and thiomalic acid without gold both caused a dose-dependent growth inhibition of both cell lines when used in the concentration range 25-300 $\mu \mathrm{mol} / \mathrm{l}$ culture medium and for four days' exposure. MT, despite binding about one third of the cytosolic gold, did not protect against the antiproliferative effect of sodium aurothiomalate. The gold and the thiomalate moieties were distributed differently within the cells; $30 \%$ of the cellular gold and $80 \%$ of the thiomalate were recovered in the cytosol. Gold was mainly protein bound in both cell lines, as shown by G75 Sephadex gel filtration of the cytosols. In the $\mathrm{HE}_{100}$ cells about $30 \%$ of the gold eluted with MT. The thiomalate eluted mainly with substances with molecular weights less than 1000 . Cellular synthesis of MT was not observed during sodium aurothiomalate treatment. The results indicate that the sodium aurothiomalate molecule dissociates and support the suggestion that the thiomalate moiety is, in part, responsible for the antiproliferative effect of the drug.

Key phrase: drug resistance.

Metallothionein (MT) is the name given to a group of low molecular weight isoproteins $(6000-7000)$ with a unique amino acid composition, in that $30 \%$ of the 61 amino acid residues are cysteine. MT has the capacity to bind certain heavy metals. ${ }^{1}$ The protein is widely distributed among different animal species and seems to occur in all tissues but is found mainly in the cytosol of liver and kidney cells. ${ }^{1}$ Cadmium (Cd) is the most potent MT inducer metal known at present, and MT is probably important in the detoxification of chronic $\mathrm{Cd}$ intoxications. ${ }^{1}$

Sharma and McQueen ${ }^{2}$ and Mogilnicka and $\mathrm{Webb}^{3}$ have shown the occurrence of low molecular

Accepted for publication 23 July 1985.

Correspondence to Dr Anne Glennås, Division of Clinical Pharmacology, Institute for Surgical Research, Rikshospitalet, N-0027 Oslo 1, Norway. weight gold-binding proteins in the liver and kidneys of rats after intramuscular administration of the gold-containing drug, sodium aurothiomalate, to the animals. These proteins have not been fully characterised, but their behaviour on gel filtration columns suggests that they may be of MT nature. The biological functions of the proteins have not yet been studied.

We have previously shown that cultured human cells containing high amounts of cadmium-induced cytosolic MT are resistant to the antiproliferative effects of $350 \mu \mathrm{mol}$ gold(III) chloride/I culture medium $^{4}$ and $2 \mu \mathrm{mol} / 1$ of the antiarthritic drug, auranofin. ${ }^{5}$ These concentrations when given continuously were lethal to the parent cell line with undetectable levels of cytosolic MT. The demonstration of the binding of gold to the MT within the 
resistant cells led to the conclusion that MT may act as one protective factor against the growth inhibitory effect of the two gold-containing compounds.

The purpose of the present study was to investigate the possible protective role of MT against the antiproliferative effect of sodium aurothiomalate. Cultured human cells with and without detectable amounts of cytosolic MT were used. The cellular concentrations and cytosolic distribution of the gold and the thiomalate moieties of the drug were investigated. For comparison, the cells were also exposed to thiomalic acid without gold.

\section{Materials and methods}

\section{CELLS AND CELL CULTURING}

The cells were human epithelial cells (HE) derived from normal skin (NCTC 2544) and obtained from the American Type Culture Collection, Maryland, USA. They were grown as monolayers in Dulbecco's modification of Eagle's medium (Flow Laboratories, Irvine, Scotland) supplemented with serum, antibiotics, and mycostaticum. ${ }^{4} \mathrm{~A}$ substrain $\left(\mathrm{HE}_{100}\right)$ had previously been adapted to $100 \mu \mathrm{mol}$ $\mathrm{CdCl}_{2} / \mathrm{l}$ culture medium, an otherwise lethal concentration for the cells. ${ }^{6}$ There is considerable evidence that the $\mathrm{Cd}$ resistance of these cells is due to induction of MT synthesis and the binding of $\mathrm{Cd}$ to MT. About $2-3 \%$ of the cytostolic proteins in these cells are estimated to be MT. ${ }^{7}$ Characterisation of the cells by methods including transmission electron microscopy, surface antigen typing, and isoenzyme analysis ${ }^{8}$ has confirmed their epithelial and human nature. Flow cytometric studies, cellular glutathione determinations, ${ }^{78}$ two-dimensional polyacrylamide gel electrophoresis of cellular proteins, and preliminary studies on DNA repair capacity ${ }^{9}$ have shown no major differences between the HE and $\mathrm{HE}_{100}$ cells, apart from the Cd-MT content.

\section{DRUGS AND CHEMICALS}

Disodium auro $\left[2,3-{ }^{14} \mathrm{C}_{2}\right]$ thiomalate (specific activity $0.31 \mathrm{mCi} / \mathrm{mmol})$ and $\left[2,3-{ }^{14} \mathrm{C}_{2}\right]$ thiomalic acid (specific activity $0.88 \mathrm{mCi} / \mathrm{mmol}$ ) were kindly supplied by Rhône-Poulenc (May \& Baker Ltd, Dagenham, Essex, England). The radiochemical purity of the ${ }^{14} \mathrm{C}$-labelled disodium aurothiomalate was determined at the start of the experiments by thin layer chromatography (TLC) with $n$-butanol/ glacial acetic acid/water $80: 20: 20$ on silica gel plates (Polygram Sil G/UV 254, Schleicher \& Schull GmbH, Dassel, W Germany). Subsequent determination of radioactivity in sections of the plates indicated a radiochemical purity of $90 \%$. The purity of the labelled thiomalic acid was $68 \%$ as estimated by TLC with toluene/methanol/glacial acetic acid
45:8:4 on silica gel. Batches of sodium $\left[{ }^{199} \mathrm{Au}\right] \frac{\stackrel{2}{3}}{3}$ aurothiomalate (specific activity $123.5 \mathrm{mCi} / \mathrm{mmol}$ 므. and $163.0 \mathrm{mCi} / \mathrm{mmol}$ ) were synthesised at the Department of Biophysics, University of Manches- $\vec{F}$ ter. Sodium aurothiomalate (Myocrisin) was the commercially available drug, and thiomalic acid was $\frac{0}{-}$ purchased from Sigma Chemical Company, Mo, $\frac{\bar{c}}{\bar{\omega}}$ USA. The thiomalic acid was stored under nitrogen $\vec{\nabla}_{\bar{\sigma}}$ until use, and all compounds were protected from $\propto$ light. Fresh solutions of the drugs were prepared forw each experiment. Cadmium chloride purum was $\vec{\circ}$ obtained from Fluka AG, Switzerland.

CELL GROWTH STUDIES

Cells from both cell lines ( $\mathrm{HE}$ and $\mathrm{HE}_{100)}$ ) were? subcultured into Costar tissue culture wells $(16 \mathrm{~mm})$ iे (Costar, Maryland, USA) at a density of $1.0 \times 10^{4} \mathrm{i}$ cells per well. The $\mathrm{HE}_{100}$ cells were removed from $\vec{\circ}$ the Cd-containing medium, and all cells were grown without metal supplement for $24 \mathrm{~h}$. Cultures were옹 then exposed to medium containing $25,50,100,200$, or $300 \mu \mathrm{mol}$ of sodium aurothiomalate or thiomalate derived from thiomalic acid per litre of culture medium. Controls were grown without drug supplementation. Cells from six replicate wells of each cell line, drug, and drug concentration were harvest $\mathrm{g}_{\infty}$ by trypsinisation and counted in a Coulter counterat.

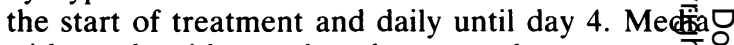
with and without the drug supplements weres changed on day 2 . On day 4 the viability of the cells was tested by the dye exclusion test (trypan® blue). ${ }^{10}$ Differences in sensitivity to the drugs $\frac{\Phi}{\square}$ between the cell lines were calculated by means of $\overrightarrow{\vec{P}}$ an area method (see Appendix).

CELLULAR CONCENTRATION AND DISTRIBUTION OF ${ }^{199} \mathrm{~A} u$ AND ${ }^{14} \mathrm{C}$

After removal of the $\mathrm{Cd}$ supplement for $24 \mathrm{~h}$ क्ष exponentially growing $\mathrm{HE}$ and $\mathrm{HE}_{100}$ cells were exposed to $300 \mu \mathrm{mol} / \mathrm{l}$ of sodium $\left[{ }^{199} \mathrm{Au}\right]$ auro thiomalate, disodium auro $\left[2,3-{ }^{14} \mathrm{C}_{2}\right]$ thiomalate, orô $\left[2,3-{ }^{14} \mathrm{C}_{2}\right]$ thiomalic acid for another $24 \mathrm{~h}$. The cell cytosols were then obtained by ultrasound sonication? and ultracentrifugation $\left(105000 \mathrm{~g}, 1 \mathrm{~h}, 4^{\circ} \mathrm{C}\right)$. $>$ Aliquots of sonicates and cytosols were analysed for을. radioactivity and for protein content (Abbot $\bar{N}$ bichromatic analyser 100) with human albumino (Behringwerke AG, W Germany) as a standard. N Differences in concentrations and the distribution N of ${ }^{199} \mathrm{Au}$ and ${ }^{14} \mathrm{C}$ were tested by Student's $t$ test, taking significance as $\mathrm{p}<0 \cdot 05$. The remaining cytosols were chromatographed on a G75 Sephadex column $(1.6 \times 90 \mathrm{~cm})$ with $10 \mathrm{mM}$ ammonium formate buffer $\mathrm{pH} 8$ as eluent. The elution rate was $18 \mathrm{ml} / \mathrm{h}$ and the fraction volume $3 \mathrm{ml}$. The concen-0 trations of $\mathrm{Cd}, \mathrm{Zn}$, and $\mathrm{Cu}$ in the eluted fractions 
were determined by atomic absorption spectrophotometry (Instrumentation Laboratories aa/ae spectrophotometer 257 ). The ${ }^{199} \mathrm{Au}$ concentration was determined with a gamma scintillation spectrometer (Packard 5221). The counting efficiency was $35 \%$ with a $120-185 \mathrm{keV}$ window. The ${ }^{14} \mathrm{C}$ activity was determined in a Mark II liquid scintillation system (Tracor Analytic Inc., Ill., USA). Each fraction showed a similar degree of quenching. The counting efficiency determined by an external standard ratio method for ${ }^{14} \mathrm{C}$ was $89 \%$. The coefficients of variation (standard deviation corrected for background as a percentage of net counts) of the counts per minute had a range of $0 \cdot 2-1 \cdot 1 \%\left({ }^{199} \mathrm{Au}\right)$ and $0 \cdot 5-2 \cdot 7 \%\left({ }^{14} \mathrm{C}\right)$ for the gel filtration peaks and $1 \cdot 0-3 \cdot 3 \%\left({ }^{199} \mathrm{Au}\right)$ and $20 \cdot 8-32 \cdot 3 \%\left({ }^{14} \mathrm{C}\right)$ for the regions between the peaks.

IN-VITRO INCUBATION OF Cd-MT AND ISOTOPE-LABELLED SODIUM

A U ROTH IOMA LATE

Cd-induced MT, obtained after G75 Sephadex gel filtration of cytosols from $\mathrm{HE}_{100}$ cells as described above, was dissolved in $10 \mathrm{mM}$ ammonium formate buffer $\mathrm{pH} 7 \cdot 5$. The concentration of MT was approximately $10 \mu \mathrm{mol} / \mathrm{l}$. Sodium $\left[{ }^{199} \mathrm{Au}\right]$ aurothiomalate or disodium auro[2,3- $\left.{ }^{14} \mathrm{C}_{2}\right]$ thiomalate was added to a final drug concentration of $20 \mu \mathrm{mol} / \mathrm{l}$ and incubated for $1 \mathrm{~h}$ at $20^{\circ} \mathrm{C}$. The drug concentration used was equal to the cytosolic gold concentration after drug exposure of living cells. After a second G75 Sephadex gel filtration run the concentrations of ${ }^{199} \mathrm{Au},{ }^{14} \mathrm{C}, \mathrm{Cd}$, and $\mathrm{Zn}$ in the eluted fractions were determined.

INCUBATION OF ${ }^{14}$ C-LABELLED SODIUM AUROTHIOMALATE WITH CULTURE MEDIUM To examine the distribution of $\mathrm{Au}$ and ${ }^{14} \mathrm{C}$ the culture medium was supplemented with $300 \mu \mathrm{mol} / \mathrm{l}$ of disodium auro $\left[2,3-{ }^{14} \mathrm{C}_{2}\right]$ thiomalate and incubated for $24 \mathrm{~h}$ in tissue culture flasks without cells. After G75 Sephadex chromatography of the medium the ${ }^{14} \mathrm{C}$ concentration in the eluted fractions was determined as above. The Au concentration was determined by flame atomic absorption spectrophotometry.

\section{Results}

EFFECT OF SODIUM AUROTHIOMALATE AND THIOMALIC ACID ON CELL GROWTH The growth of $\mathrm{HE}$ and $\mathrm{HE}_{100}$ cells during exposure to $25-300 \mu \mathrm{mol} / 1$ of sodium aurothiomalate for four days is shown in Fig. 1. Fig. 2 shows the cell growth during exposure to equimolar concentrations of

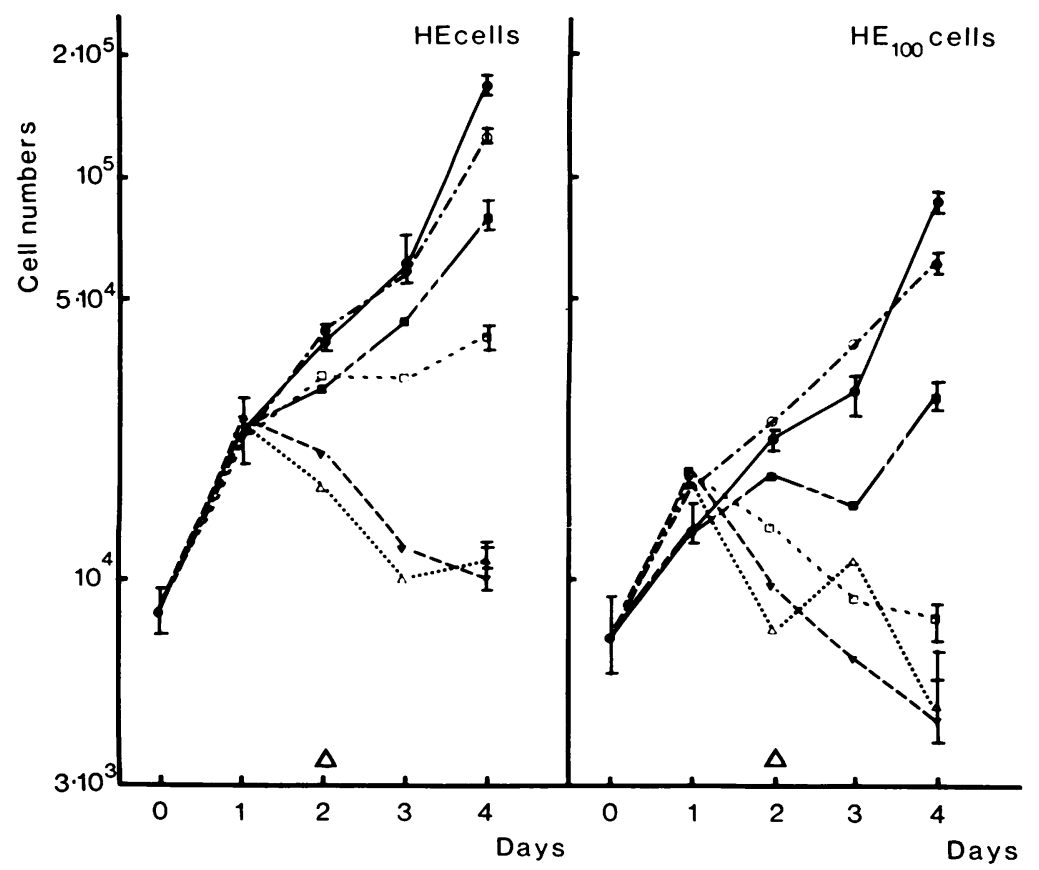

Fig. 1 Growth of $H E$ and $H E_{100}$ cells on exposure to $25(\mathrm{O}-\mathrm{O})$, 50 (口- - - $\mathrm{\square}), 100$ ( $\square-\mathrm{-}-\mathrm{\square})$, $200(\nabla--\nabla)$, or $300(\triangle \ldots . . \Delta)$ umol sodium aurothiomalate/l culture medium for four days. Controls (-) were grown without drug supplement. $\triangle$ indicates medium change. Each point is the median of six replicates. Bars indicate the 25th and 75 th percentiles for the distribution of cell counts. 


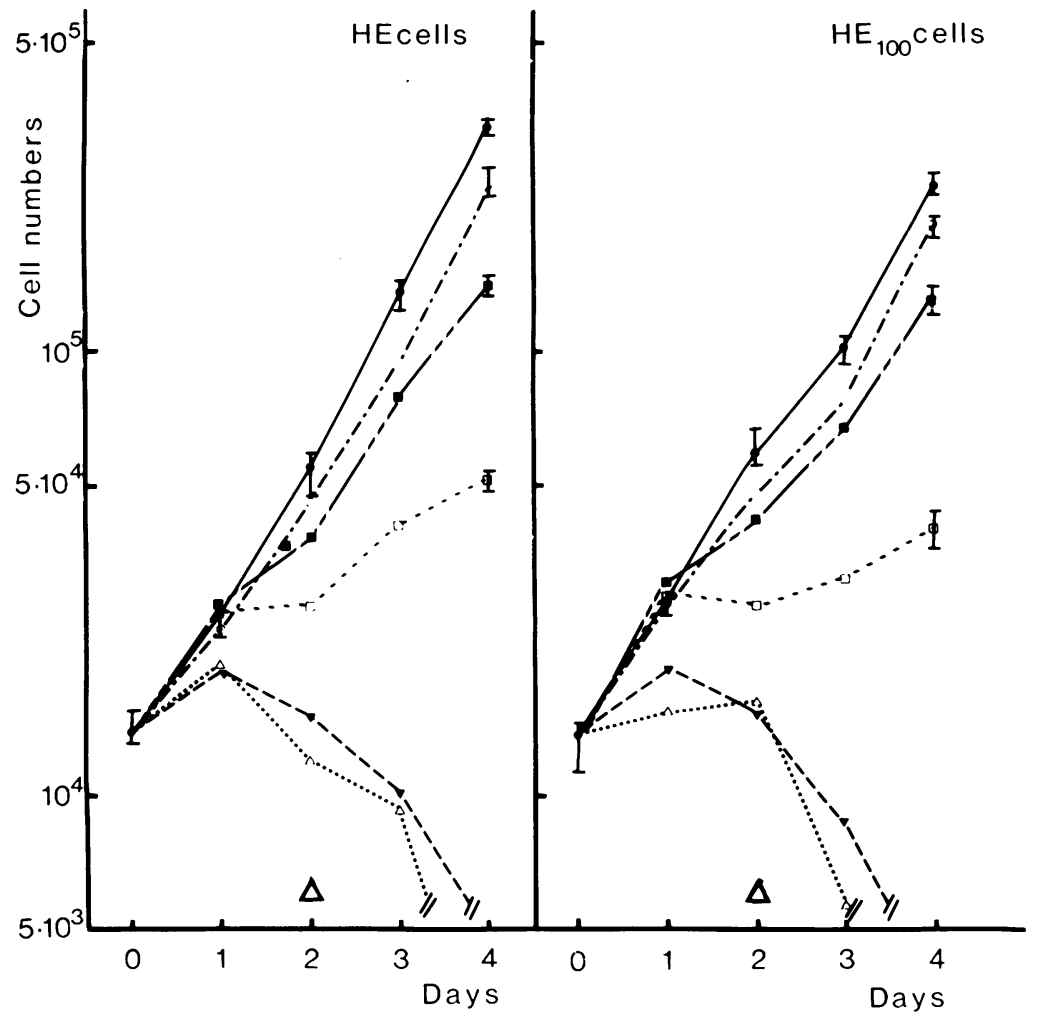

Fig. 2 Growth of $H E$ and $H E_{I O 0}$ के cells on exposure to 25 (O- - - $)$ ), $\overrightarrow{0}$

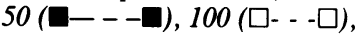
$200(\boldsymbol{\nabla}---\nabla), \operatorname{or} 300(\triangle \ldots \Delta)$ umol thiomalate derived from thiomalic acid/l culture medium for four days. Controls were grown without drug supplement. $\triangle$ indicates medium change. Each point is the median of six replicates. Bars indicate the 25th and 75 th percentiles for the distribution of cell counts.

thiomalate derived from thiomalic acid. Both compounds caused a dose-dependent growth inhibition of both cell lines. No significant differences between the $\mathrm{HE}$ and $\mathrm{HE}_{100}$ cells were detected in the responses when grown with sodium aurothiomalate or thiomalate. On day 4 of treatment with $300 \mu \mathrm{mol}$ sodium aurothiomalate $/ 16.5 \%$ (percentage of median values for the cell counts) of the $\mathrm{HE}$ cells and $5.4 \%$ of the $\mathrm{HE}_{100}$ cells remained adherent to the wells compared with the control cells. On treatment with $300 \mu \mathrm{mol}$ thiomalate/ $0.7 \%$ of the HE cells and $0.7 \%$ of the $\mathrm{HE}_{100}$ cells remained attached. The viability of the remaining cells was more than $85 \%$. At concentrations of sodium aurothiomalate or thiomalate higher than $100 \mu \mathrm{mol} / \mathrm{l}$ all cells detached from the wells and died within about two weeks.

\section{CELLULAR CONCENTRATIONS OF ${ }^{199} \mathrm{Au}$ A N D ${ }^{14} \mathrm{C}$}

The concentrations of ${ }^{199} \mathrm{Au}$ and ${ }^{14} \mathrm{C}$ in sonicates and cytosols after $24 \mathrm{~h}$ exposure of the cells to 300 $\mu \mathrm{mol} / \mathrm{l}$ of either sodium $\left[{ }^{199} \mathrm{Au}\right]$ aurothiomalate, disodium auro $\left[2,3-{ }^{14} \mathrm{C}_{2}\right]$ thiomalate, or $\left[2,3-{ }^{14} \mathrm{C}_{2}\right]$ thio- $-\frac{\overrightarrow{0}}{3}$ malic acid are shown in Table 1. After exposure to the ${ }^{1099} \mathrm{Au}$ - or ${ }^{14} \mathrm{C}$-labelled aurothiomalate ${ }^{199} \mathrm{Au}$ and ${ }^{14} \mathrm{C}$ were recovered in the cells (sonicates) in equimolar concentrations, $9.5-13.2 \mathrm{nmol} / \mathrm{mg}$ sonicate protein. No significant differences wereo found between the $\mathrm{HE}$ and $\mathrm{HE}_{100}$ cells in either ${ }^{199} \mathrm{Au}$ or ${ }^{14} \mathrm{C}$ content. About $30 \%$ of the cellularo ${ }^{199} \mathrm{Au}$ and $80 \%$ of the cellular ${ }^{14} \mathrm{C}$ derived from the thiomalate moiety were recovered in the cytosol.o Accordingly, the cytosolic ${ }^{199} \mathrm{Au}$ concentrations were lower than those of ${ }^{14} \mathrm{C}, 5 \cdot 0-6 \cdot 1 \mathrm{nmol}{ }^{199} \mathrm{Au} /$ 을. mg cytosol protein and $18 \cdot 0-23 \cdot 3 \mathrm{nmol}{ }^{14} \mathrm{C} / \mathrm{mg}$ cytosol protein respectively. No significant differ- $\Omega$ ences in the cytosolic concentrations of ${ }^{199} \mathrm{Au}$ and 0 ${ }^{14} \mathrm{C}$ between the $\mathrm{HE}$ and $\mathrm{HE}_{100}$ cells were detected. ${ }_{\mathrm{W}}$ When the cells were exposed to the ${ }^{14} \mathrm{C}$-labelledo thiomalate derived from thiomalic acid, similar or slightly higher concentrations and a similar distribution of ${ }^{14} \mathrm{C}$ between the sonicates and cytosols was found compared with that found after exposure of the cells to the ${ }^{14} \mathrm{C}$-labelled disodium aurothioma-o late. 
Growth inhibitory effect of sodium aurothiomalate on cultured human cells

Table 1 Concentrations of ${ }^{199} \mathrm{Au}$ or ${ }^{14} \mathrm{C}$ in sonicates and cytosols of $H E$ and $H E_{100}$ cells*

\begin{tabular}{|c|c|c|c|c|c|c|}
\hline \multirow[t]{2}{*}{ Isotopeldrug } & \multicolumn{3}{|l|}{$H E$ cells } & \multicolumn{3}{|c|}{$H E_{I O D}$ cells } \\
\hline & Sonicate & Cytosol & $\begin{array}{l}\% \text { of cellular } \\
{ }^{199} \mathrm{Au} \text { or }{ }^{14} \mathrm{C} \\
\text { in cytosol }\end{array}$ & Sonicate & Cytosol & $\begin{array}{l}\% \text { of cellular } \\
{ }^{199} \mathrm{Au} \mathrm{or}{ }^{14} \mathrm{C} \\
\text { in cytosol }\end{array}$ \\
\hline $\begin{array}{l}{ }^{199} \mathrm{Au} \text { from sodium }\left[{ }^{199} \mathrm{Au}\right] \\
\text { aurothiomalate } \\
{ }^{14} \mathrm{C} \text { from disodium }\end{array}$ & $9 \cdot 5 \pm 6 \cdot 1$ & $6 \cdot 1 \pm 5 \cdot 0$ & $35 \cdot 3 \pm 16 \cdot 5$ & $11 \cdot 3 \pm 8 \cdot 6$ & $5 \cdot 0 \pm 3 \cdot 4$ & $30 \cdot 0 \pm 16 \cdot 4$ \\
\hline $\begin{array}{l}\text { auro }\left[2,3-{ }^{14} \mathrm{C}_{2}\right] \text { thiomalate } \\
{ }^{14} \mathrm{C} \text { from }\left[2,3-{ }^{-14} \mathrm{C}_{2}\right]\end{array}$ & $12 \cdot 0 \pm 1 \cdot 6$ & $18 \cdot 0 \pm 6 \cdot 4$ & $77 \cdot 5 \pm 0 \cdot 7$ & $13 \cdot 2 \pm 2 \cdot 5$ & $23 \cdot 3 \pm 5 \cdot 1$ & $80 \cdot 5 \pm 3 \cdot 5$ \\
\hline thiomalic acid & $20 \cdot 4 \pm 3 \cdot 4$ & $34 \cdot 8 \pm 0 \cdot 7$ & $81 \cdot 5 \pm 0 \cdot 7$ & $18 \cdot 9 \pm 4 \cdot 9$ & $31 \cdot 1 \pm 1 \cdot 9$ & $82 \cdot 0 \pm 2 \cdot 8$ \\
\hline
\end{tabular}

${ }^{*}$ Concentrations (nmol/mg protein) are means \pm SD from three $\left({ }^{199} \mathrm{Au}\right)$ or two $\left({ }^{14} \mathrm{C}\right)$ experiments. See methods section for details.
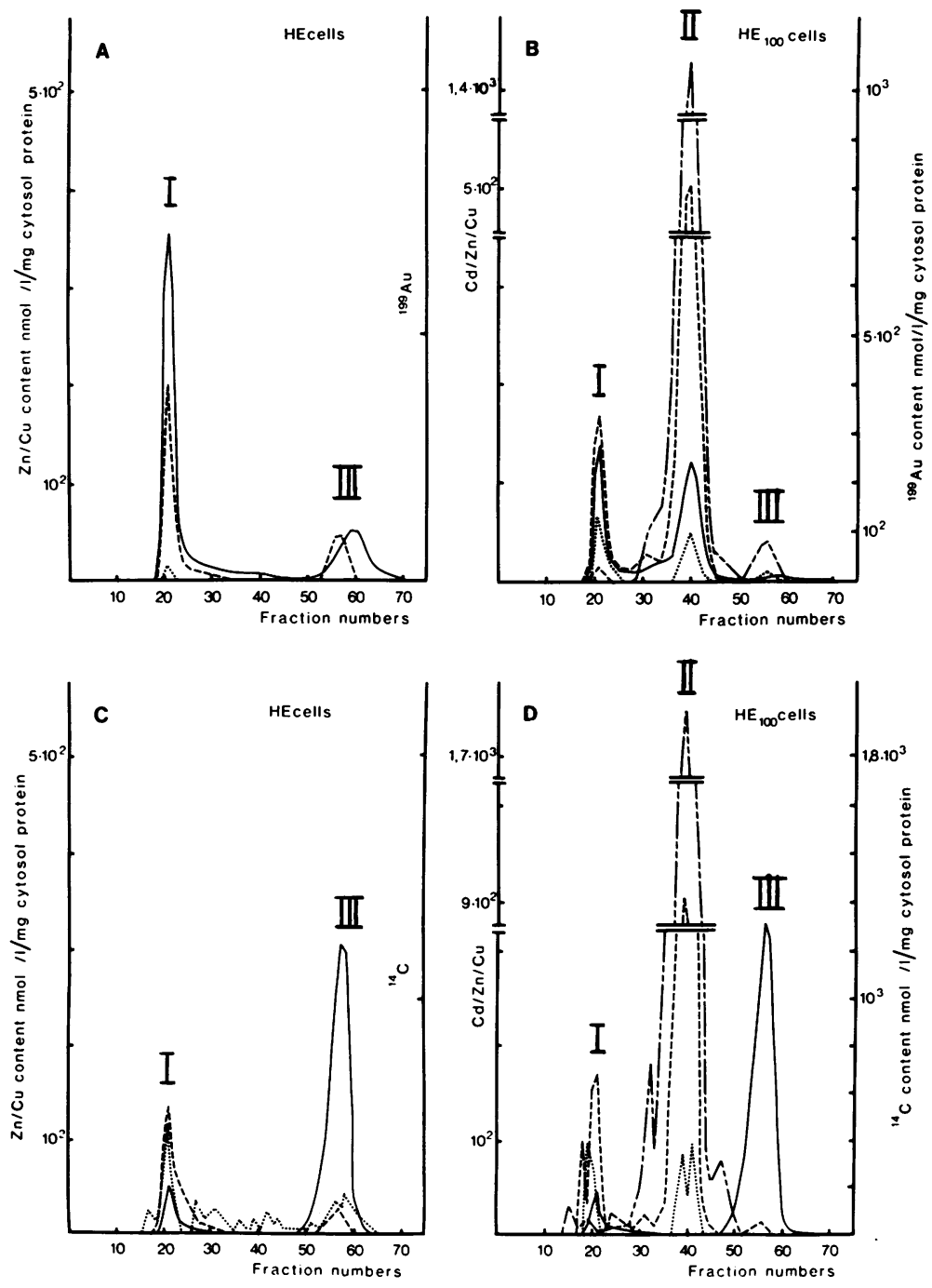

Fig. 3 Elution profiles of ${ }^{199} \mathrm{Au}$ $(-), C d(---), \operatorname{Zn}(--)$, and Cu (. . . .) obtained after $G 75$ Sephadex gel filtration of cytosols from $H E$ and $H E_{100}$ cells after exposure to sodium $I^{199}$ AuJaurothiomalate (panel $A-B)$. Elution profiles of ${ }^{4} \mathrm{C}(-), \mathrm{Cd}(---), \mathrm{Zn}(---)$, and $\mathrm{Cu}(. .$.$) obtained in the$ same way and after treatment of $H E$ and $H E_{100}$ cells with disodium auro $\left[2,3-{ }^{14} C_{2}\right.$ ]thiomalate (panel C-D). 

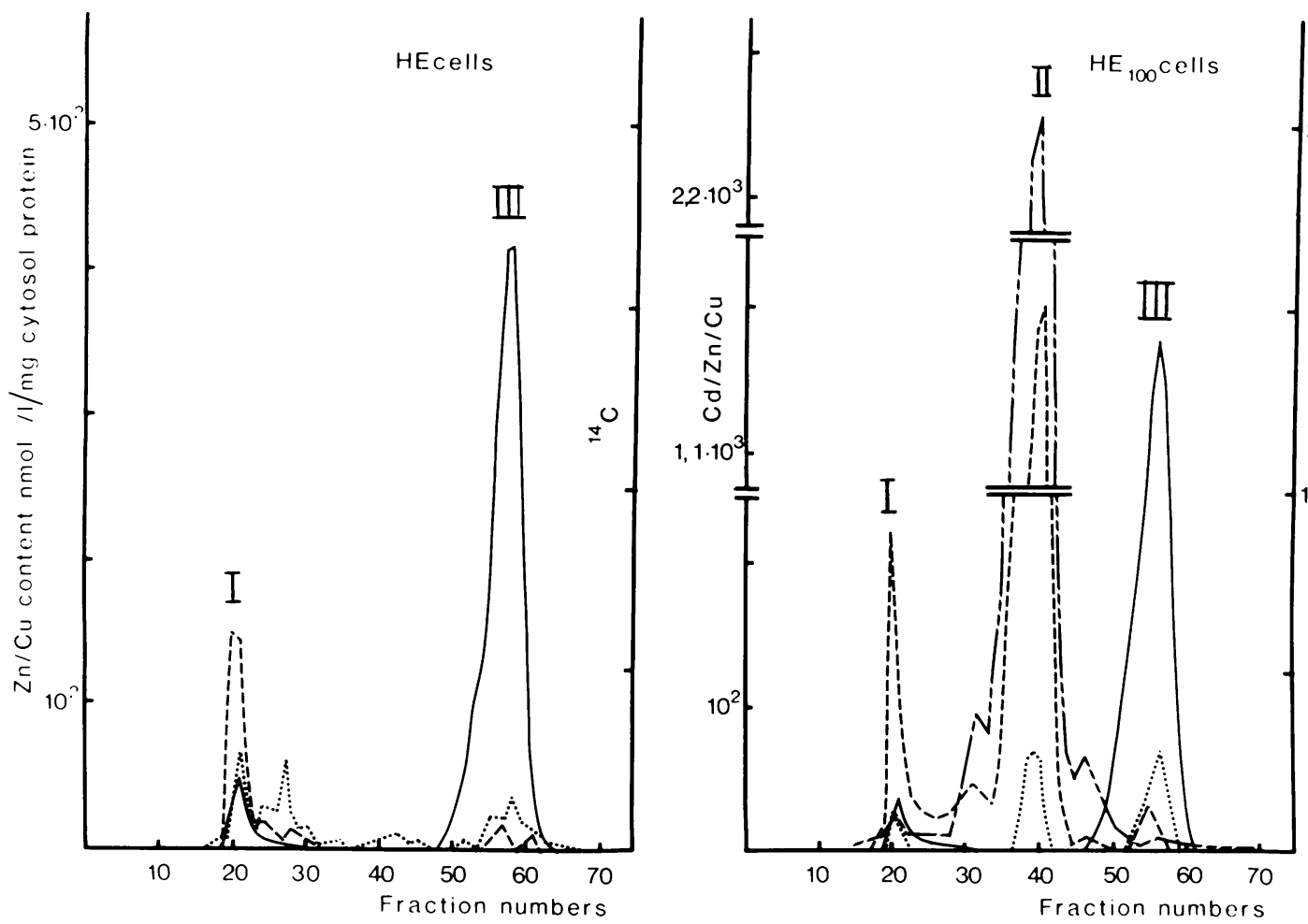

Fig. 4 Elution profiles of ${ }^{14} \mathrm{C}(-), \mathrm{Cd}(---), \mathrm{Zn}(---)$, and $\mathrm{Cu}(. \ldots)$ after $\mathrm{G} 75$ Sephadex gel filtration of cytosols from $\mathrm{HE}$ and $H E_{100}$ cells after treatment with $\left[2,3-{ }^{14} C_{2}\right]$ thiomalic acid.

Distribution OF ${ }^{199} \mathrm{~A}$ u AND ${ }^{14} \mathrm{C}$ Within THE CYTOSOLS

The G75 Sephadex elution profiles of ${ }^{199} \mathrm{Au},{ }^{14} \mathrm{C}, \mathrm{Cd}$, $\mathrm{Zn}$, and $\mathrm{Cu}$ after gel filtration of cytosols from $\mathrm{HE}$ and $\mathrm{HE}_{100}$ cells treated with sodium $\left[{ }^{199}\right.$ Aulaurothiomalate, disodium auro $\left[2,3-{ }^{14} \mathrm{C}_{2}\right]$ thiomalate, or $\left[2,3-{ }^{14} \mathrm{C}_{2}\right]$ thiomalic acid are shown in Figs 3 and 4. The fraction of ${ }^{199} \mathrm{Au}$ eluting with the void volume proteins (peak $\mathrm{I}, \mathrm{V}_{\mathrm{e}} / \mathrm{V}_{\mathrm{o}}=1$, mol.wt $>75000$ ) was $72 \%$ in $\mathrm{HE}$ and $46 \%$ in the $\mathrm{HE}_{100}$ cytosols. In the $\mathrm{HE}_{100}$ cytosols $36 \%$ of the ${ }^{199} \mathrm{Au}$ coeluted with the Cd-induced MT (peak II, $\mathrm{V}_{\mathrm{e}} / \mathrm{V}_{\mathrm{o}} \approx 2$, mol.wt $\approx 10000$ ). No such peak was observed in the $\mathrm{HE}$ cytosols, as indicated by the profiles of ${ }^{199} \mathrm{Au}$, $\mathrm{Zn}$, and $\mathrm{Cu} .7 \%$ of the ${ }^{14} \mathrm{C}$ eluted with the void volume proteins, whereas $88 \%$ eluted with substances of molecular weights less than 1000 (peak III, $\mathrm{V}_{\mathrm{e}} / \mathrm{V}_{\mathrm{o}} \approx 3$ ). This pattern was the same in both lines and after treatment with both of the ${ }^{14} \mathrm{C}$-labelled compounds. No ${ }^{14} \mathrm{C}$ activity was detected in the MT-containing fractions of the $\mathrm{HE}_{100}$ cytosols.
IN-VITRO BINDING OF ISOTOPE-LABELLED SODIUM AUROTHIOMALATE TO Cd-MT Fig. 5 shows the coelution of ${ }^{199} \mathrm{Au}$ derived from sodium $\left[{ }^{199} \mathrm{Au}\right]$ aurothiomalate and $\mathrm{Cd}$ derived fromo MT after in-vitro incubation of the drug with MT and subsequent gel filtration. About $29 \%$ of the Cdo bound to MT was exchanged with ${ }^{199} \mathrm{Au}$ under the conditions described. When MT was incubated with을 disodium auro[2,3- $\left.{ }^{14} \mathrm{C}_{2}\right]$ thiomalate, ${ }^{14} \mathrm{C}$ and $\mathrm{Cd}$ de- $>$ rived from $\mathrm{MT}$ eluted separately on the gel filtration을. column.

DISTRIBUTION OF A A AND ${ }^{14} \mathrm{C}$ IN THE CULTURE MEDIUM

After G75 Sephadex gel filtration of mediumo incubated with disodium auro[2,3- $\left.{ }^{14} \mathrm{C}_{2}\right]$ thiomalateo about $65 \%$ of the $\mathrm{Au}$ and $35 \%$ of the ${ }^{14} \mathrm{C}$ distributed $\frac{\text { C }}{\bar{D}}$ with the medium proteins. The major part of the ${ }^{14}$ ? eluted with fractions containing substances of molecular weights less than 1000 (profiles noto무 shown). 

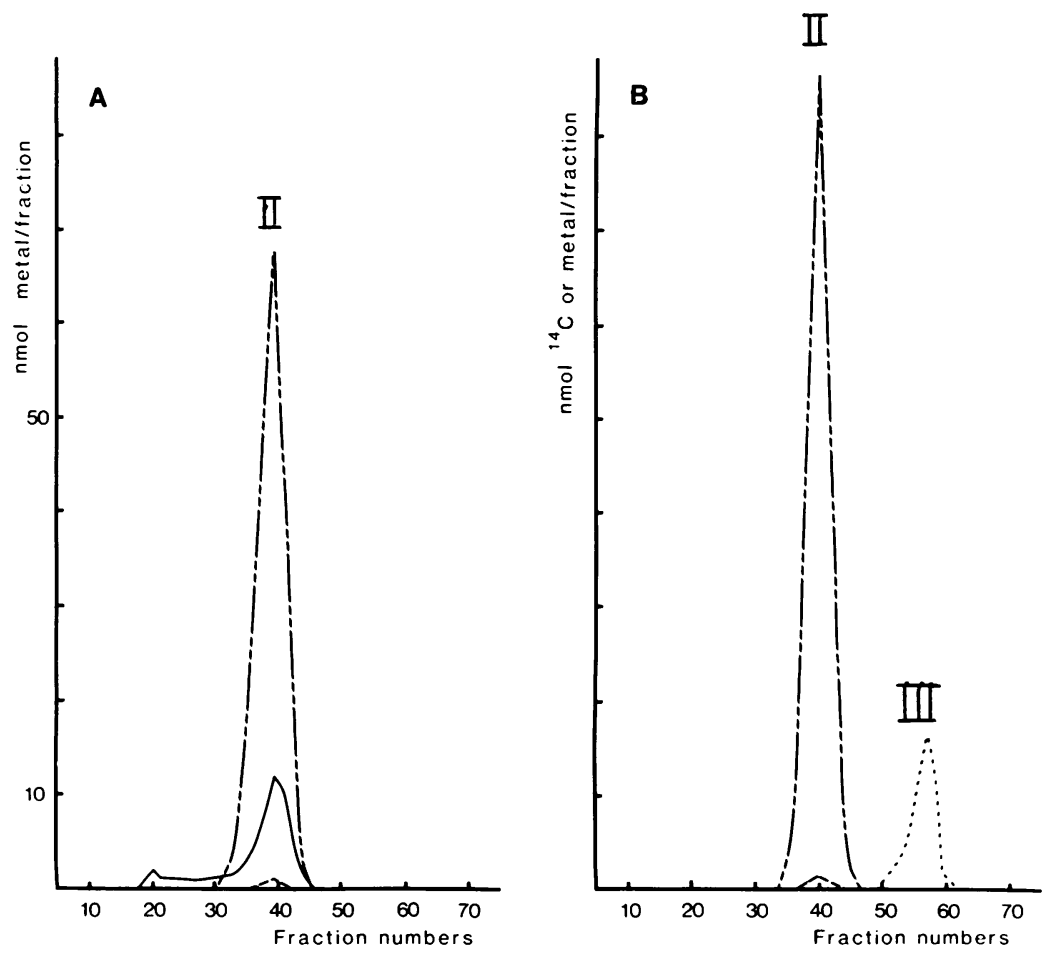

Fig. 5 Elution profiles of ${ }^{199} \mathrm{Au}(-), \mathrm{Cd}(---)$, and $\mathrm{Zn}(---)($ panel $A)$ and ${ }^{14} \mathrm{C}(-)$, $C d(--)$, and $\mathrm{Zn}(---)$ (panel B) after G75 Sephadex gel filtration of $C d$-induced $M T$ incubated in vitro with sodium $\left[{ }^{199}\right.$ Aulthiomalate or disodium auro $\left[2,3-{ }^{14} C_{2}\right]$ thiomalate. The $C d-M T$ was obtained from a previous 675 Sephadex run of cytosols from $H E_{100}$ cells.

\section{Discussion}

The present study shows that cellular Cd-induced MT has the capacity to bind gold when human cells are cultured in the presence of sodium aurothiomalate. Cd-MT also binds gold after in vitro incubation with sodium aurothiomalate. The degree of $\mathrm{Cd}$ exchange by Au was somewhat higher (29\%) after in-vitro incubation than after treatment of living cells (16\%) (Fig. 3B). An almost complete exchange of MT-bound Cd by Au was achieved in vitro when an even higher concentration of sodium aurothiomalate $(9 \mathrm{mmol} / \mathrm{l}$, data not shown) was used. MT does not confer resistance to the antiproliferative effect of the drug, despite binding about $36 \%$ of the cytosolic gold in living cells. This contrasts with the results obtained when auranofin was given to the same cells. ${ }^{5}$ The concentration of $2 \mu \mathrm{mol}$ auranofin/l culture medium caused an almost complete arrest of growth of the $\mathrm{HE}$ cells, whereas the $\mathrm{HE}_{100}$ cells continued to grow exponentially. About $15 \%$ of the cytosolic gold derived from auranofin was bound to the $\mathrm{MT}$ in the $\mathrm{HE}_{100}$ cells.

The gel filtration profiles (Figs 3 and 4) gave no indication of induced MT synthesis in the HE cells after $24 \mathrm{~h}$ of sodium aurothiomalate treatment. This does not rule out the possible induction of MT, which has been observed after sodium aurothiomalate administration to rats. ${ }^{2}{ }^{3}$ In-vivo alterations in tissue metal distribution caused by gold treatment may indirectly induce MT via zinc or copper, as suggested by Mogilnicka and Webb. ${ }^{11}$

The gold and the thiomalate derived from sodium aurothiomalate have different intracellular distributions. In the present study the thiomalate distributes similarly regardless of whether it originates from sodium aurothiomalate or thiomalic acid without gold. The thiomalate was mainly present in the cytosol, whereas the gold was recovered mainly in the pellet after ultracentrifugation. Furthermore, most gold was protein bound within the cytosol, while the thiomalate obviously appeared as the thiomalate anion, as its own disulphide, or as mixed disulphides with sulphydryl-rich oligopeptides. This indicates a dissociation of the sodium aurothiomalate molecule in the cells. Evidence was also obtained that this dissociation takes place even in the culture medium, before the drug penetrates the cells. Preliminary data indicate that the major part of the cytosolic thiomalate is free thiomalate and not its corresponding disulphide (unpublished results). The present results are in accordance with the 
studies of Jellum et al., ${ }^{12} 13$ who showed that the gold and thiomalate moieties separate in vivo after intramuscular administration of $\left[{ }^{195} \mathrm{Au}^{14}{ }^{14} \mathrm{C}\right]$ aurothiomalate to mice and rats, resulting in proteinbound gold and release of thiomalate. Other in vivo studies ${ }^{14-16}$ have confirmed the different distribution of the gold and thiomalate both in animals and humans. The present study shows that the gold and the thiomalate moieties behave differently even within cells.

The results discussed above and the closely similar growth inhibitory effects of sodium aurothiomalate and thiomalate derived from thiomalic acid raise the question of which part of the sodium aurothiomalate molecule is responsible for the antiproliferative effect observed. The possibility that the thiomalate moiety in part mediates the effect ascribed to sodium aurothiomalate cannot be excluded. Other studies $^{17}$ have shown that thiomalic acid exerts effects similar to those of D-penicillamine, a thiolcontaining antiarthritic drug, on various models of immunologically mediated inflammation in vivo, and in vitro on the responsiveness of lymphocytes to concanavalin A in the presence or absence of macrophages. Munthe and Jellum, ${ }^{18}$ in a preliminary study on five patients, suggested that thiomalic acid may have an antiarthritic effect when used in the treatment of rheumatoid arthritis.

In our experiments the concentration range of sodium aurothiomalate used was 25-300 $\mu \mathrm{mol} / \mathrm{l}$ culture medium. Thus the lower concentrations correspond to the serum gold levels obtained when the drug is used clinically. The peak serum gold concentration after the intramuscular administration of $50 \mathrm{mg}$ sodium aurothiomalate is reported to be $30-45 \mu \mathrm{mol} / \mathrm{l}$, and the trough values to be $4-25 \mu \mathrm{mol}$ gold/l at steady state conditions on chronic treatment with $50 \mathrm{mg}$ every fourth week or every week. ${ }^{1920}$ The maximum concentration used was that which caused complete growth arrest of the HE cells without causing significant cell death within the experimental period. When compared on this basis the concentration of auranofin equally effective to $300 \mu \mathrm{mol} / 1$ of sodium aurothiomalate is about 2 $\mu \mathrm{mol} / 1 .{ }^{5}$ This probably reflects the differences in cellular affinity ${ }^{21}$ and in toxicity ${ }^{22}$ between the two drugs. It may also support the suggestion that the antiproliferative effect of gold-containing drugs may be ascribed to drug components other than the gold moiety or in addition to it.

In conclusion, we have shown that human cells containing high amounts of cytosolic MT are not resistant to the antiproliferative effect of sodium aurothiomalate, though MT traps about one third of the cytosolic gold. Sodium aurothiomalate exposure does not induce the synthesis of detectable amounts of MT. Sodium aurothiomalate and thiomalic acid 3 have similar growth inhibitory effects. The observed $\frac{\text { N }}{}$. differences in the cellular and cytosolic distributions: of gold and thiomalate indicate a dissociation of thes sodium aurothiomalate molecule and raise questionso about the effector moiety of the molecule.

We are grateful to Mrs K R Modalsli, Miss K Moestue, and Miss A K Syversen for excellent technical assistance, to Dr H L Sharma (Department of Medical Biophysics, University of Manchester $\mathscr{\infty}$ England) for synthesising sodium $\left[{ }^{199} \mathrm{Au}\right]$ aurothiomalate. and May $\rightarrow$ \& Baker Ltd who provided the ${ }^{14} \mathrm{C}$-labelled compounds. $\mathrm{Dr}$ L. Mørkrid provided statistical advice. A Glennås is a research fellow $\overrightarrow{\mid}$ sponsored by the Norwegian Hydro Company.

\section{Appendix}

The relative sensitivity of the two cell lines $\mathrm{HE}$ and $H E_{10 \%}$ too sodium aurothiomalate or thiomalic acid was calculated as follows: $N$ Cell growth was expressed by the formula:

$$
\mathrm{N}(\mathrm{t})=\mathrm{N}_{0} \exp \{\mathrm{f}(\mathrm{t}, \mathrm{c})\}
$$

where $\mathrm{N}$ is the cell number at time $(\mathrm{t})$ and $\mathrm{c}$ is the drug concentration used.

The following expression was obtained for the area under the음 curves (AUC) (Figs 1 and 2) by integration from $t=0$ to $t=T$ :

$$
A U C_{T}=\int_{0}^{T} \ln N(t) d t=T \ln N_{0}+\int_{0}^{T} f(t, c) d t
$$

$A U C_{0}=T$ In $N_{0}$ was the same for all values of $c$, $\triangle A U C=A U C_{T}-A U C_{0}$ was independent of $N_{0}$, the cell number on day 0 .

The relative sensitivity to various concentrations of the dr $\mathrm{Y}(\mathrm{c})$, of one cell line was expressed as:

$$
\mathrm{Y}(\mathrm{c})=\triangle \mathrm{AUC}(\mathrm{c}) / \triangle \mathrm{AUC}(\mathrm{c}=0)
$$

$\Delta Y /\left(Y^{\prime}+Y\right)=\left(Y^{\prime}-Y\right) /\left(Y^{\prime}+Y\right)$ was a linear first-order function of $\log \mathrm{c}, \mathrm{Y}$ denoting the values for the $\mathrm{HE}$ cells and $\mathrm{Y}^{\prime}$ those for the $\overline{\mathrm{O}}$ $\mathrm{HE}_{100}$ cells. Differences in sensitivity to the drugs were tested by a 3 significant correlation between the $\triangle \mathrm{Y} /\left(\mathrm{Y}^{\prime}+\mathrm{Y}\right)$ and $\log \mathrm{c}$, taking significance as $\mathrm{p}<0.05$.

\section{References}

1 Kägi J H R, Nordberg M, eds. Report from the firsto international meeting on metallothionein and other low molecu- 3 lar weight metal binding proteins, Zurich, 1978. Experientiai 1979; 35 (suppl 34): 1-378.

2 Sharma RP, McQueen E G. The binding of gold to cytosolic proteins in the rat liver and kidney tissues: metallothioneins.음 Biochem Pharmacol 1980; 29: 2017-21.

3 Mogilnicka E, Webb M. Comparative studies on the distribu tion of gold, copper and zinc in the livers and kidneys of rats and hamsters after treatment with sodium $\left[{ }^{195} \mathrm{Au}\right]$ aurothiomalate. $] \overline{\mathrm{N}}$ Appl Toxicol 1981; 1: 287-91.

4 Glennås A, Bakka A, Rugstad H E. Cultured human cells withn a high content of metallothionein show resistance against gold-chloride. Scand J Rheumatol 1983; 12: 321-4.

5 Glennås A, Rugstad H E. Acquired resistance against aurano-O fin in cultured human cells. Scand $J$ Rheumatol (in press).

6 Rugstad H E, Norseth T. Cadmium resistance and content of cadmium-binding protein in cultured human cells. Nature $1975 ; \Phi$ 257: 136-7.

7 Bakka A, Endresen L, Johnsen A B S, Edminson P D, Rugstad H E. Resistance against cis-dichlordiammineplatinum in cul- $\bar{O}$ tured cells with a high content of metallothionein. Toxicol Applत्( Pharmacol 1981; 61: 215-26. 
8 Ree K, Johnsen A S, Rugstad H E, Bakka A, Hovig T Characterisation of a human epithelial cell line with special reference to its ultrastructure. Acta Pathol Microbiol Immunol Scand $[A]$ 1981; 89: 73-80.

9 Endresen L, Thorsrud A K, Jellum E, Willard-Gallo K E, Rugstad H E. Protein mapping of two metallothionein-rich cell strains and their parent lines, using high-resolution twodimensional electrophoresis. Anal Biochem 1984; 143: 170-8.

10 Phillips H J. Dye exclusion test for cell viability. In: Kruse P F $\mathrm{Jr}$, Patterson M K Jr, eds. Tissue culture. Methods and applications. New York: Academic Press, 1973: 406-8.

11 Mogilnicka E, Webb M. The effects of cadmium and copper on the renal uptake and metallothionein binding of gold in the rat and hamster. Chem Biol Interact 1982; 40: 247-56.

12 Jellum E, Munthe E, Guldal G, Aaseth J. Gold and thiol compounds in the treatment of rheumatoid arthritis. Scand $J$ Rheumatol 1979; 8 (suppl 28): 28-36.

13 Jellum E, Munthe E. Guldal G, Aaseth J. Fate of the gold and the thiomalate part after intramuscular administration of aurothiomalate to mice. Ann Rheum Dis 1980; 39: 155-8.

14 Turkall R M. Bianchine J R. In vivo fate of the gold-sulfur bond of gold sodium thiomalate [Abstract]. Fed Proc 1980; 39: 2582.

15 Jellum E, Munthe E. Fate of the thiomalate part after intramuscular administration of aurothiomalate in rheumatoid arthritis. Ann Rheum Dis 1982; 41: 431-2.

16 Rudge S R, Perrett D, Swannell A J. Free thiomalate in plasma and urine of patients receiving sodium aurothiomalate. Ann Rheum Dis 1984; 43: 66-9.

17 Arrigoni-Martelli E, Bramm E, Binderup L. D-Penicillaminelike activity of thiols. Eur $J$ Rheumatol Inflamm 1978; 1: 197-203.

18 Munthe E, Jellum E. Tolerance and effectiveness of sodium thiomalate without gold in rheumatoid arthritis [Abstract]. Scand J Rheumatol 1980; 9 (suppl 33): 21.

19 Gottlieb N L. Comparative pharmacokinetics of parenteral and oral gold compounds. J Rheumatol 1982; 9 (suppl 8): 99-109.

20 Blocka K L N, Landaw E M. The organic gold compounds: comparative pharmacokinetics. In: Capell H A, Cole D S, Manghani K K, Morris R W, eds. Auranofin. Amsterdam: Elsevier, 1983: 32-44. (Excerpta Medica, Current Clinical Practice Series No 7).

21 Herrlinger J D, Alsen C, Beress R. Hecker U, Weikert W. Distribution of gold in serum erythrocytes and white blood cells after in vitro incubation and during chrysotherapy with different gold compounds. J Rheumatol 1982; 9 (suppl 8): 81-9.

22 Payne B J, Walz D T. The toxicity of three gold compounds in laboratory animals. Vet Pathol 1978; 15 (suppl 5): 1-3. 